\title{
THE PLEIADES AS OPENINGS, THE MILKY WAY AS THE PATH OF BIRDS, AND THE GIRL ON THE MOON: CULTURAL LINKS ACROSS NORTHERN EURASIA
}

\author{
Yuri Berezkin
}

\begin{abstract}
The Baltic-Finnish and the Baltic (Latvian and Lithuanian) cosmonyms mostly coincide while the Baltic and Slavic cosmonymic patterns are different. The Pleiades in the Eastern Baltic are 'a sieve', the Milky Way is 'the path of migratory birds' and a girl holding water pails is seen on the Moon. Across most of Central, Western and Southern Europe the Pleiades are 'a hen with its chicken', the Milky Way and the lunar spots have other (and different) interpretations. The Eastern Baltic pattern is identical with the Middle Volga one where it is widespread among both Finnish-Permian and Turkic groups and probably relates back to the (Proto-Baltic?) culture of the Iron Age. However, parallels for the cosmonyms in question are found across most of Northern Eurasia and find corresponding similarities in some parts of North America. 'Water-carrier on the Moon' is the most widespread of these motifs being known in Japan and Polynesia. In Eurasia, the Northern Samoyeds noticeably lack all three images. The initial emergence of at least some of the cosmonyms under discussion in the Terminal Pleistocene of northern East Asia and their further dissemination towards the West, down to the Baltics, is a hypothesis to be checked.
\end{abstract}

Key words: Asian-American cosmonymic links, folk astronomy, lunar spots, prehistory of Northern Eurasia, the Milky Way, the Pleiades

Seven objects in the night sky attracted attention in Eurasian cultures outside the Tropical Zone. These are the Moon with dark spots on its disc, Venus, the Milky Way, the Big Dipper, the Pleiades, the Belt of Orion, and Polaris. Other planets, stars and constellations were also singled out by some cultures, yet ignored by others. Though the number of Eurasian cosmonyms is great, most of them are either rare or are mere variants of a few dominant ways of interpretation. The conservatism of cosmological vocabulary and of mythopoetic ideas which underlie it makes them a good source of data on the past's ethnocultural development.

The cosmonymic map of Europe lets us infer that this past may have been rather distant. The areal distributions of several cosmonyms recorded recently, 
or preserved in written sources, do not coincide with the borders of linguistic families. In particular, cosmonymic vocabularies of the Balts and the Baltic Finns are identical even though the languages of these peoples belong to two unrelated families. Everywhere in the Eastern Baltic the Milky Way is the 'path of (migratory) birds', the Pleiades are a 'sieve', and a girl with pails in her hands is seen on the Moon. However, everywhere to the south and west of the Baltic Sea, excluding those areas of Poland and Belorussia where Baltic languages were relatively recently replaced by Slavic languages (Gładyszowa 1960; Niebrzegowska 1999: 149; Vaiškūnas 2004: 169-170), the Eastern Baltic-type cosmonymy is absent and exceptions are few. The 'path of birds' is known to the Lusitanian Sorbians (Azimov \& Tolstoi 1995: 118); the interpretation of the Pleiades as a sieve was recorded among Hungarians (Mándoki 1963: 519-520; Zsigmond 2003: 434) and in a few cases among Italians (Volpati 1932: 206; 1933b: 21); and 'girl on the Moon' is typical for Macedonia and North-Eastern Bulgaria, with a few cases in Romania (Marinov 2003: 28; Mladenova 2006: 137, 263-264, map 29; Tsenev 2004: 47).

Despite the exceptions mentioned, there is clearly a basic cosmonymic border between the Balts and the Slavs. The absence of such a border between Balts and Baltic Finns is also not subject to doubt. What historical processes could produce such a boundary?

\section{THE PLEIADES AS OPENINGS IN THE SKY}

We begin with the Pleiades. Putting aside the association of the Pleiades with a group of people (images of this sort are recorded in various areas but are very different from each other), three basic variants are widespread in Europe (Fig. 1. Numbers: 1 'hen with chickens', 2 'wild duck's nest', and 3 'sieve').

The cosmonym 'hen with its chickens', 'brood', 'chickens', 'pullets' and the like are typical for Western, Southern and Central Europe, the Balkans, and Western Ukraine (Andree 1878: 106; Boneva 1994: 12; Chubinskii 1872: 14; Janković 1951: 141; Krappe 1938: 152; László 1975: 604; Matičetov 1974: 49; Mladenova 2006: 89-93; Niebrzegowska 1999: 145; Smith 1925: 124; Sviatski 1961: 120; Volpati 1932: 194-205; 1933a: 507). Inside this zone, they are only absent across most of the territory of the former Yugoslavia and among the peoples of the Pyrenees (other than the Basques, who do have this). Outside Europe, 'hen with its chickens' is typical for West Africa and the Sudan (Hirschberg 1929: 326-327; Meek 1931: 200; Schwab 1947: 413; Spieth 1906: 557; Volpati 1933a: 507), for North-East India, and for South-East Asia (Andree 1878; Smith 1925: 114; Vathanaprida 1994: 39-41). 


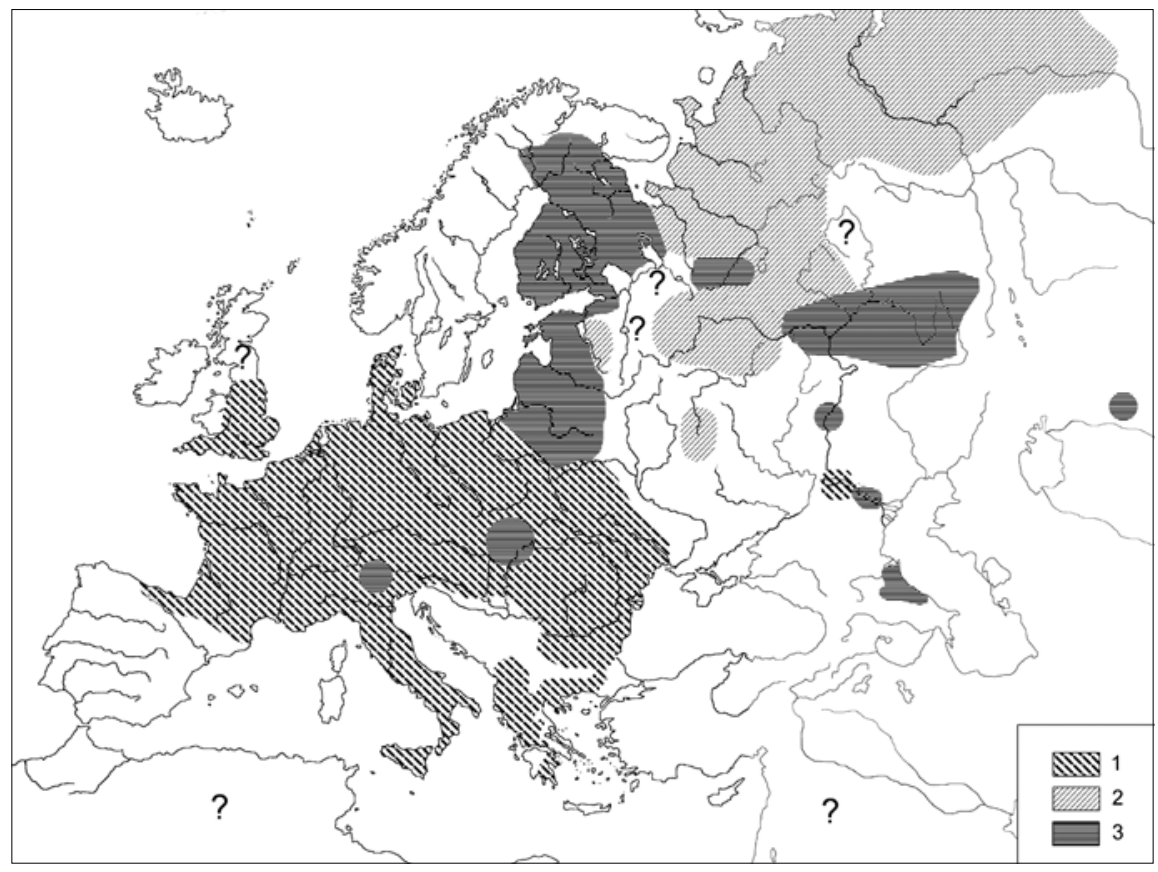

Figure 1. Major variants of the folk-names for the Pleiades in Europe: 1. Hen and chickens; 2. Brood or nest of (wild) ducks; 3. Sieve.

It is possible that in the past the same cosmonym was known in the Near East and North Africa (Volpati 1932: 195), though now the Persian-Arabic Soraya ('chandelier', i.e. a cluster of lamps) is the only word that is used for the Pleiades. The Touaregs call the Pleiades 'chickens' (Rodd 1926: 226). Because this cosmonym is lacking in ancient sources which are abundant at least for Italy (Volpati 1933a) and because it is connected only with the domestic hen, we can suggest a relatively late spread into Europe.

Cosmonyms that mean 'nest (or an egg, eggs) of a wild duck', or 'a flock of ducks' are typical for the Nenets (Khomich 1974: 232), Komi-Zyrians (Sviatski 1961: 120), Udmurts (Wichmann 1987: 214, 273), as well as for the Ob' Ugrians (Munkácsi 1908: 255; 1996; Steinitz 1966-1993: 1412, 1636). In Siberia and in Northeast Europe, a coincidence of this cosmonym with Uralic languages is noticeable, although there are a number of exceptions. Among the Selkup, the Pleiades are 'hare's shelves' or 'hare's droppings' (Tuchkova 2004: 212). The meaning of this name has been lost, and no parallels in other traditions are known. Among the Nganasans, the Pleiades are hunters who catch the souls of dead men and reindeer (Popov 1984: 48). The Enets name Kondiku (Dolgikh 1961: 24) either has no Samoyed etymology or else was greatly distorted when 
it was recorded (Sorokina 2008). On the other hand, among the Khakas, who speak a Turkic language, the Pleiades are also 'a duck's nest' or 'a flock of ducks' (Butanaev 1975: 238). The predominant position of the 'duck's nest' among northern Russians (Potanin 1883: 730; Rut 1976: 15) is a clear legacy of the pre-Slavic sub-stratum. Moving to the east of the Urals, the Russians brought the 'duck's nest' to Siberia. Citing Uno Harva, some authors claimed the existence of such an image among the Yakuts and the Kamchadals (Lundmark 1982: 105; Mladenova 2006: 196), but these statements result from a misunderstanding: Harva mistook the Russian cosmonym 'duck's nest' for a translation of the Pleiades' name from native languages (Harva 1933: 135). Maria Rut seems to have made a similar mistake discussing Enets' materials (Rut 1987: 47).

A continuous and compact area of the 'duck's nest', that is basically located inside the territory of the former spread of Uralic languages but crosses the language borders of both the Samoyeds and the Finno-Ugrians, allows us to suggest a connection of this cosmonym with some extinct people. If this people spoke a language of the Uralic family, no direct language descendents remained from this grouping.

The designation of the Pleiades as a 'sieve' is characteristic, as was mentioned, for the Eastern Baltic where it was recorded among ancient Prussians, Lithuanians, Letts, Livonians, Estonians, Votians, Finns (Allen 1899: 397; Andree 1878: 107; Ernits \& Ernits 2009; Kerbelyte 2001: 65; Kuperjanov 2003: 183-185; Mándoki 1963: 519; Nepokupny 2004; Vaiškūnas 1999: 167; 2004: 169). There are no data on the Vepses while for the Saami the Pleiades are girls (Charnoluski 1930: 48; Lundmark 1982: 105). In the Middle Volga region 'sieve', as a name for the Pleiades, has been recorded among the Chuvash (Mándoki 1963: 520; Sirotkin \& Ivanov 1970: 128; Iukhma 1980: 266; Zolotnitskii 1874: 22), Mari (Aktsorin 1991, No. 37: 83), Tatars (Potanin 1883: 729; Vorobiev \& Khisamutdinov 1967: 316), Bashkirs (Maksiutova 1973: 383), and Udmurts (probably the southern groups only) (Nikonov 1973: 376; Wichmann 1987: 107). In the Volga region, the Mordvinians are the only exception, the Pleiades being for them a 'beehive' (Sviatski 1961: 121). Such an interpretation or variants, which are more or less similar to it ('apiary', 'nest of wasps'), are also known to Russians, Ukrainians, Bulgarians, and Hungarians (Mladenova 2006: 115). Among Russians, 'sieve', as a name for the Pleiades, has been recorded in Vologda Province and among Russian migrants in areas beyond the western border of Russian ethnic territory (Rut 1987: 15; Sviatski 1961: 121).

Besides the Eastern Baltic and Middle Volga areas, 'sieve' is typical for Dagestan where it is recorded among the Kumyks, Laks, Avars, Andi, Dargins, and Tavli (Gamzatov \& Dalgat 1991: 304-305; Potanin 1883: 729-730). Grigori Potanin found 'sieve' as a name for the Pleiades among the Kazakh of the Middle 
Zhuz and among Astrakhan Tatars (Potanin 1881: 126; 1919: 84). A suggested Persian parallel (Nepokupny 2004: 80) is wrong: words Parvin ('the Pleiades', from the 'first') and parvizan ('sieve') do not share the same root (SteblinKamenski 2008). Among Chukchi and Koryak of the Asian North-East, W. Bogoras and W. Jochelson recorded cosmonyms Ke'tmet and Kä'tmäc (Bogoras 1939: 29; Jochelson 1908: 122) and translated them as 'small sieve', though at least among the Chukchi the basic image of the Pleiades was 'group of women' (Bogoras 1939: 24). A word similar to Ketmet really means 'sieve' (for washing salmon roe) though not in the Paleoasiatic but in the Yukaghir language (Mudrak 2008).

There are two basic, compact and large, areas for the Pleiades as 'sieve', the Eastern Baltic and the Middle Volga. Historically, they have in common a Baltic sub-stratum or Baltic influence (Napolskikh 1997: 158-161), and the Battle-Axe and Corded Ware cultures spread there in the earlier period (I do not here address the question whether there was a continuity between the bearers of these archaeological cultures and the proto-Balts). Later in the Volga region this cosmonym was transmitted from Finno-Ugrians to Turkic peoples.

'Sieve' may have reached Dagestan and Kazakhstan from the Volga region in times of the Golden Horde (Napolskikh's suggestion) though such a late diffuse spreading does not fit well a specific parallel between the Lithuanians and the Laks: the sky sieve was used by God to winnow cereal grains (Khalidova 1984: 160; Nepokupny 2004: 77). Unfortunately, the Lithuanian mytheme is known only from a literary source (Mickiewicz 1955, book 8: 434), from which it is not sufficient to draw reliable conclusions. The position of Hungarian materials is also unclear as although the Hungarian word szita for the Pleiades is borrowed from Slavic (Mándoki 1963: 519-520), the constellation in the sky is really viewed as something with openings (Zsigmond 2003: 434). The fact that the Hungarians are the only people in the Balkans who have this concept makes it doubtful that such an interpretation of the Pleiades was borrowed from the Slavic population of Pannonia. And if the Hungarians brought it from the East, what was the source? In Western Europe the cosmonym 'sieve' (crivello) is recorded only in the Alto Adige district of Northern Italy (Volpati 1932: 206; 1933b: 21). It deserves to be mentioned that crivello is both 'sieve' and 'shovel for winnowing grain'.

To sum up, the origins of 'sieve' as a designation of the Pleiades in Europe is far from obvious as it is not clear that all versions had a single source. But if we look at the names of the star objects in the pan-Eurasian perspective, the given cosmonym can be interpreted as a particular case of a more general and more widely known image, i.e. the conception of stars as openings. 
There are Siberian parallels for this and not only the Paleoasiatic ones mentioned above. The etymology of the name of the Pleiades in Turkic languages (Ulker, Yurker, Yurkar, etc.) is disputable. According to one of the hypotheses, it is 'vent', 'to pierce' (Nikonov 1980b: 296). Anna Dybo, the leading specialist in Altai languages, does not consider this suggestion as substantiated (Dybo 2008). At the same time, it is supported for the Yakuts by a folklore text: the hero makes mittens of wolf skin to stop up holes in the sky from which the icy wind blows and these holes are the Pleiades (Holmberg 1927: 418). Among the Orochi and the Uilta of Sakhalin the Pleiades, in some cases, are also 'seven openings' (Podmaskin 2006: 432) though the 'seven women' are more usual for the Lower Amur region. No special narratives exist related to this name but the same word is used to denote the branchial openings of the lamprey (Pevnov 2008). Beyond Northern Eurasia, the conception of the Pleiades as stars surrounding an opening can be found among the Canadian Ojibwa (Speck 1915: 48). Given that there exist other Asiatic - North American parallels in mythology (Berezkin 2006), the historic connection between this image and the Siberian ideas is not excluded.

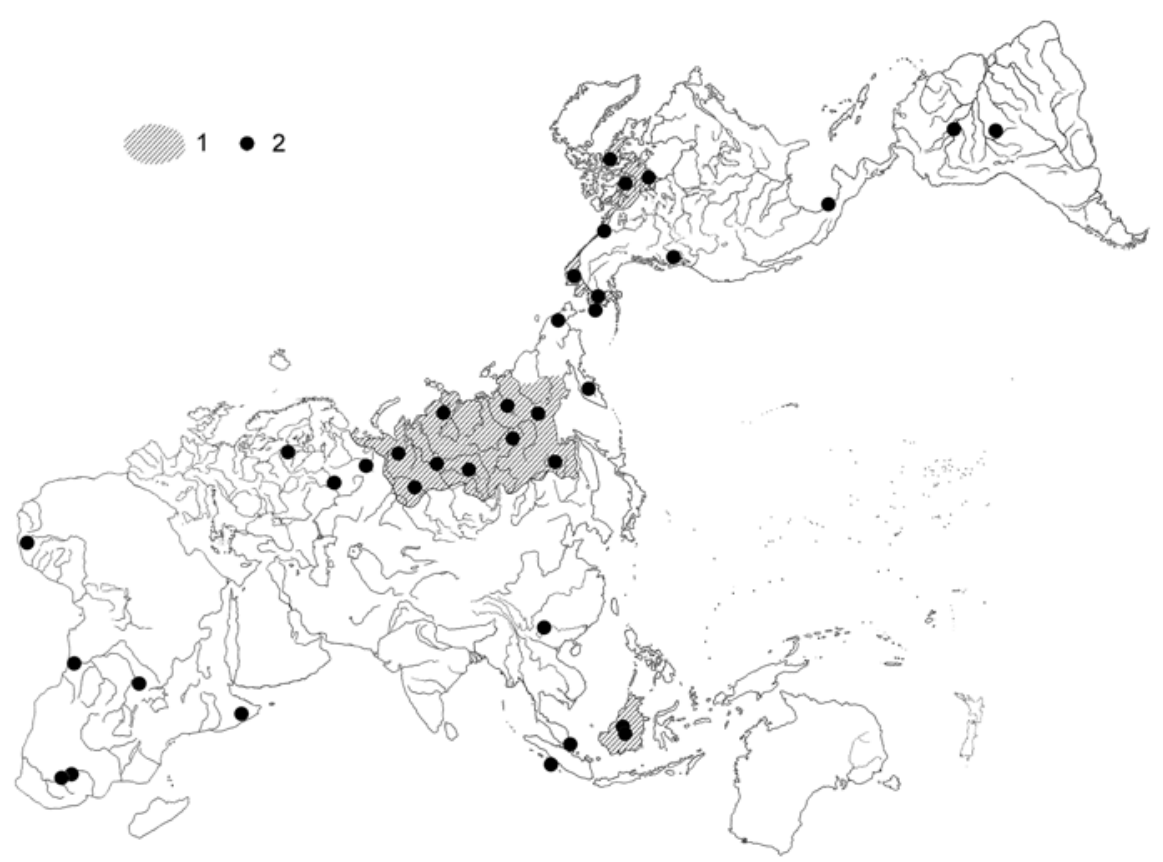

Figure 2. Areal distribution regarding the interpretation of stars as openings in the firmament. 1. Continuous distribution is probable. 2. Particular areas where the data have been received. 
If we consider not just the Pleiades but any stars regarded as openings in the sky, such a motif is known in Africa, particularly in Liberia, Congo, Somalia and South Africa (Kapchits 1997: 15-16; Koekemoer 2007: 75; Mahieu 1975: 236; Pechuël-Loesche 1907: 135; Schwab 1947: 413; Sicard 1966: 42), in western Indonesia and Malaysia, particularly among the Malay, Mentawei, Klemantan and Kayan (Hose \& MacDougall 1912: 142, 214; Schefold 1988: 71; Skeat \& Blagden 1900: 5), and in Southern China among the Miao (Its 1960: 107). Nevertheless, the conception of stars as openings is predominant only in Northern Eurasia, in the American Arctic and possibly in Borneo (Fig. 2). As isolated cases it is recorded among the Estonians (Kuperjanov 2003: 125), Mari (Aktsorin 1991, No. 26: 59-60), Komi (Ariste 2005, No. 136: 163) and seems to be a norm among the Nenets (Neniang 1997: 214, 224; Khelimski 1982: 399), Nganasans (Popov 1984: 45; Simchenko 1996: 191), Khanty (Lukina 1990, No. 8: 67-69), Kets (Alekseenko 1976: 79; Dulzon 1966: 15-17; 1972: 83-86), Yakuts (Gurvich 1977: 199; Ergis 1967: 134), Evenki (Vasilevich 1959: 161-162; Voskoboinikov 1960: 296), Evens (Lamut) (Burykin 2001: 114), and Negidals (Pevnov 2008). Indirect or vague information of a similar nature exists for the Chukchi and Kamchadal (Ergis 1974: 134; Jochelson 1961: 71-74). In North America the concept of stars as openings is typical for the Arctic where it is registered among the Central Yupiq, including Nunivak Island, Inupiat, the Mackenzie Delta, Caribou, Netsilik and Iglulik Eskimo (Lantis 1946: 197; MacDonald 1998: 33; Nelson 1899: 495; Ostermann 1942: 56, 58; 1952: 128; Rasmussen 1930: 79). This fact should be considered in relation to a hypothesis of a separate origin of the Eskimo which was different from the origins of other American natives. The image of a particular star (usually Polaris) as an opening through which one can penetrate into the upper world is known to many American Indians, but the general conception of stars, as holes in the firmament, in North and South America is recorded only rarely and among groups isolated from each other such as Thompson River Salish, Totonac, Tucuna, and Tupari (Boas 1895, No. 4: 17-18; Caspar 1975: 188; Ichon 1969: 36; Nimuendaju 1952: 123-124). An absolute majority of American natives, as well as the peoples of Africa, Australia, Oceania and the Indo-Pacific borderlands of Asia, interpreted stars taken as a particular class of objects in only one way, i.e. as persons, spirits, living creatures of some kind.

\section{THE MILKY WAY AS THE 'PATH OF BIRDS'}

The second cosmonym whose western limit coincides approximately with the border between Lithuanians and Poles is the designation of the Milky Way as the 'path of birds' (Fig. 3) or, more precisely, of migratory birds like geese, 


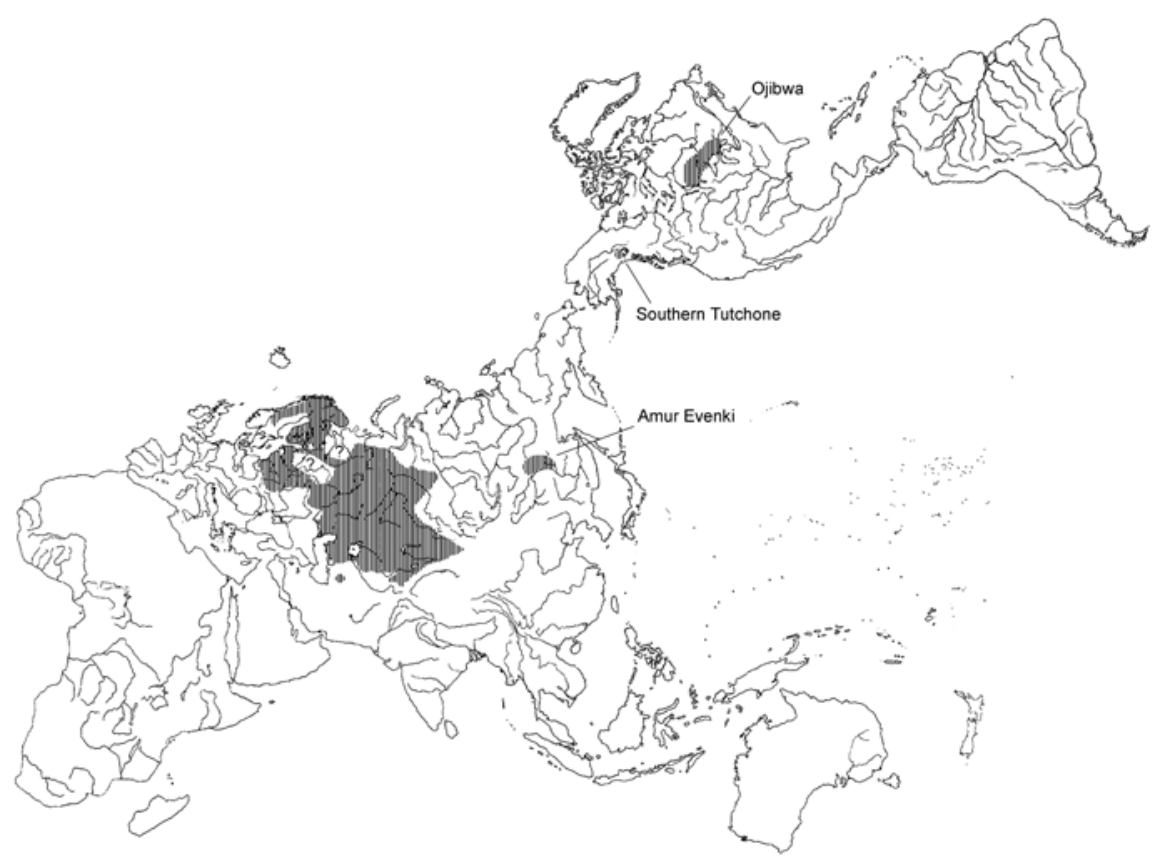

Figure 3. Areal distribution of the interpretation of the Milky Way as the path of migratory birds.

ducks, swans or cranes. Researchers sometimes see in the 'path of birds' a variant of a more general interpretation of the Milky Way as the 'route of dead souls' (Kuperjanov 2001). The two ideas are quite similar in meaning (Azimov \& Tolstoi 1995: 118), but the cosmonym 'path of birds' is still specific enough and sometimes coexists as a distinct image with the 'route of dead souls' (Aikhenwald et al. 1982: 164). The area of its spread covers only part of the territory where seasonal migrations of birds occur as a particular theme in folklore traditions. The latter is elaborated e.g. among the native peoples of Alaska, North American Northwest Coast and some South American Indians (Berezkin 2007) but 'path of birds' is unknown to most of these groups.

'The path of birds' ('path of cranes', 'birds' path', 'trace of the route of birds', etc.) is known mainly to peoples from three language families, i.e. Balts, FinnoUgrians (but excluding Samoyeds) and Turks. These include the Letts and Lithuanians (Kerbelyte 2001: 57; Gładyszowa 1960: 77-78; Vaiškūnas 1999: 173), Livonians (Toivonen 1937: 123), Estonians (Pustylnik 2002: 268; Kuperjanov 2003: 150-151), Finns (Erdödi 1968: 110-111), Saami (Erdödi 1968: 111; Toivonen 1937: 123), Mari (Aktsorin 1991: 55-56; Erdödi 1968: 110; Vasiliev 1907: 12), Mordvin (Deviatkina 1998: 118), Chuvash (Ashmarin 1984: 26; Rodionov 
1982: 168; Zolotnitskii 1874: 22), Volga Tatar (Vorobiev \& Khisamutdinov 1967: 316), Bashkir (Barag 1987: 33; Rudenko 1955: 315), Udmurt (Erdödi 1968: 110; Moshkov 1900: 197; Potanin 1883: 740; Vereschagin 1995: 81), Komi (Erdödi 1968: 110; Napolskikh 1992: 6; Potanin 1883: 943), Kazakh (Karuts 1911: 35; Potanin 1881: 126-127; Sidelnikov 1962: 268), Kirgiz (Abramzon 1946: 65; Fielstrup 2002: 217, 227; Potanin 1881: 127), Karakalpak (Nikonov 1980a: 248). The Turkmen preserved a cosmonym 'path of birds' up to the middle of the 19th century (Nikonov 1980a: 248; 1980b: 293). The same cosmonym was known also to the Khanty and Mansi (Erdödi 1968: 109-110; Munkácsi 1908: 254; Napolskikh 1992: 8) and up to the 16th century to the Hungarians (Nikonov 1980: 248) who seem to have brought it from their eastern homeland. Another name for the Milky Way which is widespread among Ob' Ugrians is 'ski trace', connected to the myth about the hunt of the sky elk (Erdödi 1968: 116). It is either the only or the most dominant name among Samoyeds and the peoples of Eastern Siberia, Lower Amur and Alaska. Among Ob' Ugrians both names are found, but they are connected with different cycles of mythological ideas.

Russians call the Milky Way 'path of geese' in Vologda, Viatka, Perm, Tula, Smolensk, and Kaluga provinces and in Siberia (Gura 1997: 671; Rut 1987: 13), as do Belorussians in Polesie near Pinsk (Gura 1997: 658), and Ukrainians in Volyn' near Lutsk (Chubinskii 1872: 15; Moshkov 1900: 205). In Southern Russia, across most of the Ukraine and among Southern Slavs this cosmonym is absent and thus its geographic spread suggests a borrowing by Slavs from a Finno-Ugric or Baltic sub-stratum, which may ultimately lead us to the same set of cultures, as does the concept 'sieve' applied to the Pleiades. At the same time, the areal coincidence of 'sieve' and 'path of birds' is not complete - the spread of the latter cosmonym is wider. It is important to add both Saami and especially Turks beyond the Volga region, i.e. the Kazakh, Kirgiz, Karakalpak and Turkmen. Nevertheless, not all Turks share this concept. The absence of the 'path of birds' among peoples of the Sayan-Altai region as well as among Uzbeks (and most probably Uigurs) makes it doubtful that this cosmonym had a proto-Turkic origin.

However the 'path of birds' is known to the Evenki of the Middle Amur area (Vasilevich 1969: 210) and in America to Algonkians who live to the north of the Great Lakes, in particular to the Ojibwa, including two groups near Lake Huron (Miller 1997: 60; Speck 1915: 79) and the Saulteaux (Hallowell 1934: 394). It is not clear if the materials of the Tutchone Athabascans, who live in Canada near the border with southern Alaska, are related to the same conception. Among the Southern Tutchone the Milky Way marks the path of the loon who had cured the blind hunter (McClelland 1975: 78). 
Taken as a whole, the distribution of the 'path of birds' does not justify attributing the origin of this cosmonym to Balts or Turks. Finno-Ugrians most probably did know the 'path of birds' from early times, but the absence of this cosmonym among Samoyeds makes it unlikely that it can be attributed to the proto-Uralic. From another side, unless it emerged independently among the Evenki and the Algonkians, this concept must have appeared in Eurasia long before the split of Proto-Uralic into two major branches.

\section{THE WATER-CARRIER ON THE MOON}

The third cosmonym whose western limits in Europe coincide approximately with the border between Balts and Slavs is the 'girl with pails on the Moon' (Fig. 4). Two tales including this are widely known. According to one, the Moon takes pity on an orphan girl, a poor step-daughter, or the like, who was sent to fetch water and so the Moon takes her up to herself. According to the other, the Moon does this as punishment for a girl or young woman who was arrogant and boastful. Since then a figure of a girl with pails can be seen on the

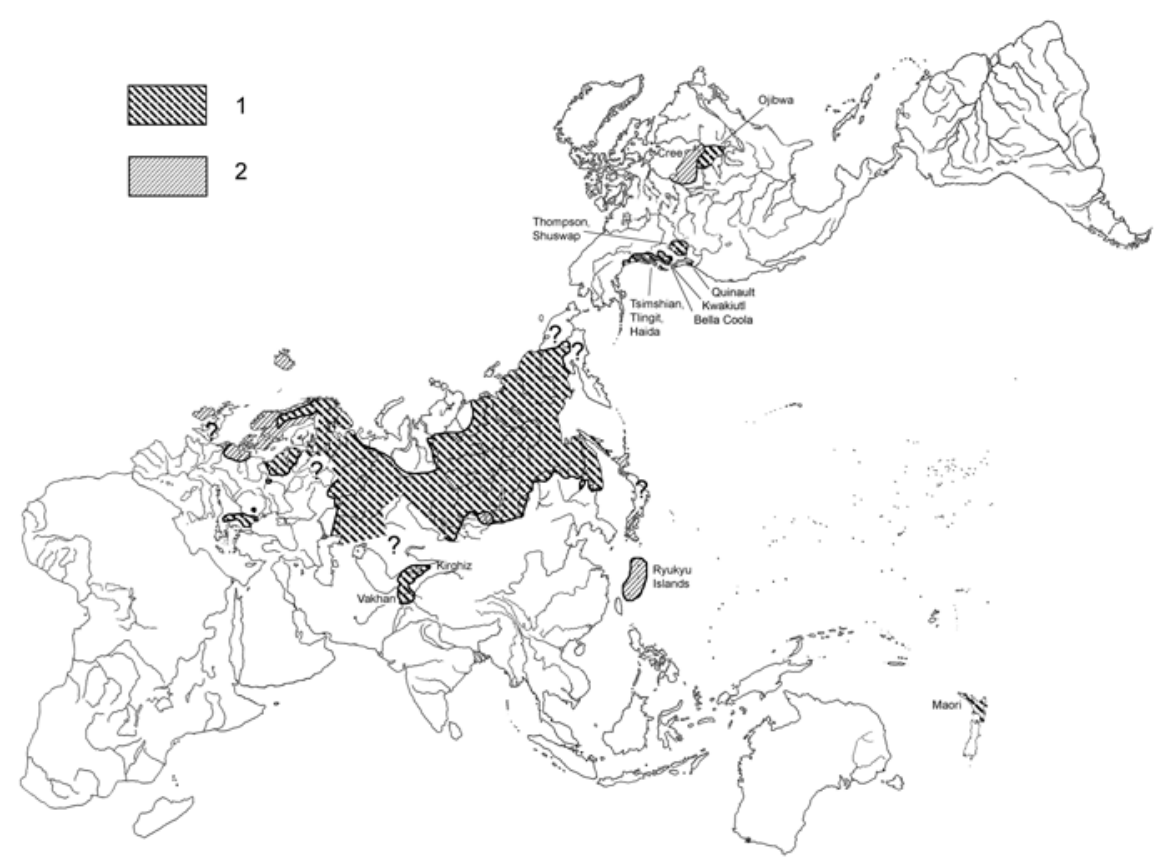

Figure 4. Areal distribution regarding the interpretation of spots on the Moon as of a figure of a person who went to fetch water and holds water pail in her or his hands. 1. Girl or young woman. 2. Two children, small boy, lad, man. 
Moon. Among Balts and Baltic Finns, in particular the Lithuanians (Kerbelyte 2001: 70; Laurinkienè 2002: 365; Vaiškūnas 2006: 158), Letts (Pogodin 1895: 440), Livonians (Loorits 2000: 318), Estonians (Kuperjanov 2003: 72; Peebo \& Peegel 1989: 282; Jüvä et al. 1995: 94), and Votians (Ariste 1974: 5; 1977: 175; Ernits \& Ernits 1984: 579) one or both of these two variants are recorded together with other, more rare, explanations. For example among the Karelians the girl holds in her hands a milk-pail (Evseev 1981: 313). No details of the Vepsian 'legends' are provided by the source (Egorov 2003: 129). Among the Saami the Sun takes the girl to give her in marriage to his son and throws her onto the Moon where she is now seen with her yoke and pails (Charnoluski 1962: 68-79). In the Volga-Permian region the 'water-carrier on the Moon' is present among Komi-Zyrians (Ariste 2005, No. 109: 105; Limerov 2005, No. 58: 55-56), Komi-Permiaks (Konakov et al. 2003: 312), Udmurts (Potanin 1883: 776; Vereschagin 1995: 85-86; Vladykin 1994: 322), Chuvash (Ashmarin 1984: 25; Denisov 1959: 15-16; Vardugin 1996: 260; Egorov 1994: 120), Mari (Aktsorin 1991, No. 37-42: 83-87; Moshkov 1900: 197), Bashkirs (Nadrshina 1985: No. 6 , 7: 12 13; Rudenko 1955: 315), Volga Tatars (Vorobiev \& Khisamutdinov 1967: 314-315). In this area, the version with an orphan girl is widely known, while the version with the woman who made fun of the Moon is absent. Bashkirs and Tatars have the story of the Moon who carried away the girl because he fell in love with her. As with the 'sieve', the Mordvin present an exception - I could not find the motif of the 'water-carrier on the Moon' in their folklore. Among Russians the motif of the 'water-carrier as a poor orphan-girl' seems to be recorded only in the Viatka Province (Belova 2004, No. 1305: 521), while the motif of a young boy and girl who went after water and were looking at the Moon too intently was recorded in Arkhangelsk Province (Gura 2006: 462). These data concerning northern Russians are hardly exhaustive because this part of regional cosmonymy has never been the focus of research. The Ukrainian 'water-carrier on the Moon' was recorded only once, in Volyn' region (Gura 2006: 262), i.e. in the same area where the 'path of birds' was also present.

Just as was the 'path of birds', so 'the water-carrier on the Moon' in its 'poor step-daughter' version is present among the Kirgiz (Brudnyi \& Eshmambetov 1968: 11-13) and the Kazakh. Kazakh materials were recently obtained in Ak Tüba Province (Stasevich 2006). Previously, Kazakh ideas about the spots on the Moon were not investigated, so the lack of data on the eastern groups of Kazakh, as well of Karakalpak, is not significant. From the Kirgiz the motif of a poor step-daughter who was sent to fetch water and was taken up onto the Moon may have spread to the Pamir region, where it is known at least to the Vakhan (Lashkarbekov 2005). 'The water-carrier on the Moon' (in its two variants 'poor step-daughter' and 'woman of indecent behavior') is recorded among 
Siberian Tatars (Valeev 1976: 329; Urazaleev 2007: 4). The motif is neither known among the Northern Samoyeds nor among the Northern Selkup. Among the Southern Selkup it is a small girl who went to fetch water, or a young girl who teased the Moon (Golovnev 1995: 330-331; Pelikh 1972: 322-323). Among the Khanty it is a small girl (alone or together with a boy) who teased the Moon (Kulemzin \& Lukina 1978, No. 4, 5: 15-16) and among the Mansi it is a girl with pails, explanations for this image seem to be lost (Ivanova 2009). Among the Ket the Moon was teased by a young girl or woman (Alekseenko 1976: 84). Among the Khakas the same story about a poor step-daughter was widespread, as also among the Kirgiz, Kazakhs (Butanaev 1975: 232). For the Altai region the motif is not typical. In only one of many narratives that describe how the ogre Tilbegen (Jelbegen, etc.) got to the Moon, the Moon took him when he went to fetch water and had a yoke and pails in his hands (Anokhin 1997: 5-6). Data on Shor and Tuvin are absent, and among the Tofa, the person who ended up on the Moon is an orphan boy sent to fetch water (Rassadin 1996, No 3: 10). In a tale of the Darkhats, who live in Mongolia near Khubsugul Lake, two boys went after water and ended up on the Moon (Nekliudov et al. 2007). Three texts with such a plot were recorded, one of them from an informant whose parents were Khalkha Mongolians but lived among the Darkhats of Khubsugul Aimak. In other areas of Mongolia the motif is unknown, and it seems that it is connected only with Siberia, not with Central Asia. The Khubsugul Darkhats relatively recently shifted to the use of the Mongolian language, and their culture is similar to that of Todzha Tuvins (Zhukovskaia 1980: 151). In the early 20 th century the Darkhat shamans still used the Tuvin language to address spirits (Sanzheev 1930: 7).

Different groups of Buryats also seem to inherit the "water-carrier on the Moon' from a pre-Mongolian sub-stratum. Among them this tale was recorded many times in a form which was near to the 'poor step-daughter': a girl's stepmother or her own mother who married another man sends her to fetch water and expresses a wish that the Moon would take her (Galdanova 1987: 17; Khangalov 1958: 319; 1960: 14; Potanin 1883: 190-193; Sharakshinova 1980: 49-50). Among several groups of Yakuts (Alekseev et al. 1995: 197-199; Gurvich 1948: 130; 1977: 199; Khudiakov 1969: 279, 372-373; Ovchinnikov 1897, No. 5-6: 179-181; Popov 1949: 260-261; Seroshevski 1896: 667; Tolokonskii 1914: 89), Evenki (Potanin 1893: 385; Rychkov 1922: 83-84; Vasilevich 1936: 73-74; 1959: 165; Voskoboinikov 1967: 159), and Lamut (Novikova 1987: 43-44), 'water-carrier on the Moon' is known mainly in its 'poor step-daughter' variant though in rare cases the motif of two children who looked at the Moon and were drawn to it is also recorded (Khudiakov 1969: 279). The 'water-carrier on the Moon', in a variant identical to the 'poor step-daughter' of the Evenki, is present among 
the Negidal (Khasanova \& Pevnov 2003: 55-56; Lopatin 1922: 330) and Nanai (Arseniev 1995: 152; Chadaeva 1990: 34-35; Lopatin 1922: 330) but not among peoples of Primorye and Sakhalin. This argues in favor of a connection of this motif in this region with Tungus and not with a pre-Tungus sub-stratum. More precisely, the Nivkh version of the 'poor step-daughter' exists but it was recorded recently (Turaev 2008: 186) and is absent among the materials of Sternberg or Kreinovich, so a late borrowing from Tungus groups is not excluded. The same image of a girl or a woman seen on the Moon and holding a pail or a scoop is, however, known to the Udihe (Podmaskin 1991, No. 17: 125) and was recorded among the Nivkh in the early 20th century (Ishida 1998: 24; Kreinovich 1973: 32-33). The Ainu of Sakhalin and Hokkaido see on the Moon a girl who went to fetch water and was taken by the Moon to become his wife (Pilsudski 1912, No. 3: 73-74; 1991, No. 3: 70-72) or who was envious and insulted the Moon accusing her of being idle (Ishida 1998: 24-25), or else the Ainu see in the lunar disc a boy who insulted the Moon in the same way (Batchelor 1927: 260). The motif of a woman seen on the Moon with pails in her hands (no other details) is known in southern Japan (Inoui 2005), while myths recorded on the Ryukyu Islands (Miyako and Okinawa) explain how a man with a waterpail ended up on the Moon (Nevski 1996: 267-269). In Northeast Asia the 'poor orphan' variant of the 'water-carrier on the Moon' is recorded among Yukaghirs (Nikolaeva et al. 1989, No. 2: 21-23) and among Russian-speaking dwellers of Markovo village who have Yukaghirs (the Chuvan) among their ancestors (Hakkarainen 1999). The 'water-carrier' is absent among Paleoasiatic peoples, though the Chukchi (Bogoras 1939: 22-23; Bogoras 1928, No. 2: 301-302), the Koryak (Beretti 1929: 36) and the Kamchadal (Porotov \& Kosygin 1969: 33) have a less specific motif of a girl who ended up on the Moon.

One particular detail is typical of Siberian texts recorded among the Khakas, Tofa, Buryat, Ket, Selkup, Khanty, Yakut, and southeastern Evenki. When the water-carrier was being taken up to the Moon, he or she tried to hold a bush and is now seen on the lunar disc holding both the pails and the bush. The same detail is present among the Vakhan of Pamir and the Koryak. In the Koryak story (Beretti 1929: 36) there is no mention of pails, but the entire episode with a girl whom her evil step-mother drove to a river to fetch water is similar to the Yakut and Evenki variants. In Southern Siberia among the Teleut, Altai, and Khakas, this motif is not linked to the water-carrier motif, and it was an ogre who attempted to hold a bush to prevent being pulled up to the Moon.

We can summarize that the motif of a girl or young woman who went to fetch water and ended up on the Moon is widespread across Eurasia from the Eastern Baltic to the Sea of Okhotsk. Adjacent to this area, variants are found 
in which either the motif of water to be fetched by a person is lost, or else the actors are a boy, a man, or two children instead of a girl. Nowhere in this periphery, with the exception of the Koryaks, does the Moon take the watercarrier up to the sky because he feels sorry for her. In addition to Mongolian, Japanese and Paleoasiatic materials, Scandinavian and Western European variants should be mentioned among the peripheral traditions. Thus in Ireland people saw on the Moon two boys who carried a stick with a pail of water on it (Krappe 1938: 120), while in Northern Germany it was a man with a pitcher in his hands, a child with a pail, a thief who carried two stolen pails with water, or two men who held yokes with water-tubs (Ishida 1998: 20-21; Krappe 1940: 168; Wolf 1929: 55-56). Also in Scandinavia, it was two children with a yoke and a pail (The Younger Edda 1970: 20) or two old men who tried to drown the Moon with water (Krappe 1938: 120).

It is of utmost interest that texts recorded beyond Eurasia are similar to the typical Eurasian variant of 'woman insults the Moon'. In particular, 'watercarrier on the Moon' is known to most peoples of the Northwest Coast of North America and of the Fraser River basin in the adjacent Plateau area.

Tlingit. One of two girls says that the Moon is like her grandmother's labret. Immediately the two girls are on the Moon. The one who insulted the Moon falls to earth and is shattered, while her friend is now seen on the lunar disc with a pail in her hand (Swanton 1908b: 453).

Haida. A woman goes to fetch water and points at the Moon, then imagines somebody sitting in the well and points at this figure. At night she gets thirsty, returns to the well, somebody grasps her hand and pulls her up. She tries to hold onto a bush of salal-berries and is now visible on the Moon carrying the bush and a pail (Swanton 1908a: 450-452).

Tsimshian (Ness River). A woman points at the Moon and at its reflection in the water. The Moon takes her to the sky while she is carrying a berrybush. Now she is seen on the Moon with the bush and the water-pail in her hands (Boas 1916: 864).

Bella Coola. A woman with a pail of water in her hands is seen on the Moon (McIlwraith 1948: 225).

Oowekeeno. A little boy is crying, his sister puts him outdoors, and gives him a toy pail to play with. He keeps crying, she warns him that the Moon will take him away. The Moon descends and takes him, now he is seen on the Moon with a little pail in his hand (Boas 1895: 217; 2002: 457).

Kwakiutl (Newtee). The Moon descends to earth, asks for some water. A girl goes out with a pail, he abducts her. When he descends again to abduct another girl, the mother of the first one warns her about danger but she too comes out with a pail of water and is now seen on the Moon holding the pail in her hands (Boas 1895: 191; 2002: 409). 
Shuswap. In winter time the Moon travels constantly. His wife asks where they are going to camp. The Moon suggests that she camp on his face. She jumps on it and is still seen there with her buckets and shovel, with which they melt snow (Teit 1909: 653).

Thompson. The Moon sends his sister to fetch water. Coming back she finds no place to sit and he suggests that she sit on his face. Now a woman with pails in her hands is seen on the Moon (Teit 1898: 91-92).

Quinault. The Moon was as bright as the Sun. Many girls desire him but he chooses the Frog. Now she is seen on the lunar disc holding a box with her property and a pail in her hands (Thompson \& Egesdal 2008: 207-209).

In the latter three texts the motif of water-carrier typical for the Northwest Coast is combined with the motif, typical for the Salish, of a person, usually the Frog-woman, clinging to the face of the Moon and seen now as spots on the lunar disc.

Beyond the Northwest Coast the water-carrier is recorded among the Algonkians to the north of the Great Lakes. In a myth of Northern Ojibwa (Sandy Lake), a woman, sending her son to fetch water, warns him not to look at the Moon. The lad disappears and is now seen on the Moon holding a ladle and a pail (Ray \& Stevens 1971: 81). This story was known to different groups of Swampy Cree with a difference that the boy is warned not by his mother but by his elder sister (Bird 2007: 36-37; Clay 1978: 28-33; Ellis 1995: 23-27, 29$33,119)$. In an Ojibwa myth recorded to the north of Lake Superior a woman cooks maple syrup and pours it from one pail into another. When the Moon sees that she urinates on the same place, the Moon is offended and takes the woman to the sky. When the Sun, who was the Moon's husband, learned of this, he punished his wife, making her carry the woman eternally. Now the woman with a pail is seen on the Moon (Jones 1919: 637).

'Water-carrier on the Moon' is known to the Maori of New Zealand. As soon as Hina scooped water with her gourd vessel, clouds hid the Moon, Hina stumbled and water poured out. Hina scolded the Moon, the Moon seized her and Hina clutched at a bush. Now she is seen on the Moon with a bush and a gourd vessel in hands (Ishida 1998: 26). In another variant, it was a man, Rona by name, who ended up on the Moon (Reed 1999, No. 16: 190-192). In yet another version, Rona is the name of a woman (Dixon 1916: 87-88). It seems that the variant was predominant which had a female person ending up on the Moon. Some incomplete parallels for this myth are found on other Polynesian islands, and water containers are seen on the Moon together with a woman (Beckwith 1970: 220-221; Dixon 1916: 88; Williamson 1933: 100). Though New Zealand is extremely remote from Siberia, the ultimate sources of the Maori myth should be looked for at the probable Austronesian homeland in East Asia 
because nothing of the kind is present in Melanesia and Indonesia. The motif of a bush grasped by a woman who came to the river and was pulled up to the Moon firmly links the Maori variant to those found among the Haida and Tsimshian, and among many Siberian peoples. To attribute the spread of tales with such specific details to the influence of the Europeans or to think that they emerged independently would be unrealistic.

\section{CONCLUSIONS}

Distributions of the three cosmonyms described above largely coincide. All three motifs are typical for the Eastern Baltic and Middle Volga region. In two cases out of three ('the Pleiades as sieve' and 'the water-carrier on the Moon') the southernmost of the Middle Volga groups, i.e. the Mordvin, is the only one in this region for which no data on these images are found. All these motifs are typical for some or for many of the northern Russian provinces and not typical for southern Russia or for the Ukraine except for a small enclave at Volyn'. It is clear that these motifs came to the Eastern Slavs from a sub-stratum population. Northern Samoyeds (Nenets, Enets and Nganasans) are not familiar with these three motifs while the Selkups, more precisely only the southern Selkups, have just one of them, the 'water-carrier on the Moon'. The 'path of birds' is known to all Finno-Ugrians and 'the water-carrier on the Moon' is known to most of them other than the Mordvin and the Hungarians. The 'path of birds' and 'the water-carrier on the Moon' are both present among Kazakh and Kirgiz, while the Altai-Sayan Turks lack them. Among the Kazakh of the Middle Zhuz, 'sieve' is recorded as a name for the Pleiades. To the east of the Yenissei River only the motif of the water-carrier on the Moon is widespread, and among the Yakut, Evenki and Buryat it was recorded many times. However, considering 'sieve" as a particular variant, applied to the Pleiades, of the motif of 'stars as openings in the firmament', the 'sieve' still connects Eastern Europe with Siberia. In addition, 'the path of birds' was also known to the Amur Evenki. The Algonkians to the north of the Great Lakes have 'the path of birds' and 'the water-carrier on the Moon', and also a possible parallel for the image of the Pleiades as an opening in the sky. 'The water-carrier on the Moon' is also typical for Indians of the Northwest Coast and for the Salish in the southern Northwest Coast and northern Plateau areas. Taking into consideration the complete absence of such motifs among American Indians who lived farther to the south than the Salish and the Ojibwa, the Siberian source of these images is plausible. If so, we have to push the dating of their spread in Eurasia back to the Early Holocene at the latest. 
When the ice caps melted, peopling of the northern territories of Eastern Europe came mainly from the south. Archaeologists trace the first post-glacial cultures of the Eastern Baltic back to the Final Paleolithic Swiderian culture and this conclusion corresponds well to data from craniology and population genetics (Niskanen 2002: 144-147). The spread of some mythological motifs also fits such a scenario (Napolskikh 1990). However, the areal patterns of the motifs reviewed above make us suggest that there was also some migration taking place from the East. Even if the Evenki and Algonkian data concerning 'the path of birds' are ignored and the motif of stars as sky-openings is not considered specific enough, the pattern of the spread of the 'water-carrier on the Moon' makes the hypothesis of trans-Eurasian migration plausible. Remembering the detailed American and Polynesian parallels for the Eastern and Southern Siberian variants, the Northern Eurasian East, rather than the West should be suggested as the earliest zone of the spread of this motif. The Bulgarian-Macedonian enclave of the 'water-carrier' clearly cannot be a source for Siberian, not to speak of Amerindian and Polynesian myths, and Bulgarian materials rather demonstrate the existence of some late Baltic-Balkan links.

To determine the origins of the 'water-carrier on the Moon' in the Balkans it would be desirable to compare the Bulgarian-Macedonian materials with Serbian ones. Unfortunately, Serbian interpretations of the spots on the Moon are of late origin and include only variants typical for most of the Christian Europe (Janković 1951: 108-109). A version which is specific to Bulgarian variants (a boy and a girl come to a well and end up on the Moon) is found elsewhere only among Northern Russians (Gura 2006: 462). The Macedonian case (the Moon saves a poor stepdaughter who now stands on the Moon with two pails of water) is close to Lithuanian, Estonian and Middle Volga versions.

During the Final Pleistocene - Early Holocene, more detailed ideas about the objects of the night sky had probably been forming in Northern and Central Eurasia. From Eurasia the corresponding ideas were brought to North America. In the Indo-Pacific borderlands of Asia, in Australia, South and Central America the cosmonymy had developed independently and does not demonstrate parallels with North Eurasian - North American set of images and plots, while in sub-Saharan Africa its development had been minimal. As new images in Siberia and Eastern Europe did not displace earlier ones but were added to them, a minimal number of small groups of migrants from the East was probably enough for spreading the new cosmonymy across most of Eurasia. If such migrants were forest hunters and fishermen, the natural limit of their western spread had to be the Baltic Sea. I think that this is the ultimate reason for differences between sets of cosmonyms in the Eastern Baltic area and in Central Europe. 


\section{ACKNOWLEDGEMENTS}

This article is supported by grant 07-06-00441-a of the Russian Foundation for Basic Research and by the project "The earliest population of Siberia and migrations to the New World", under a special program of the Presidium of the Russian Academy of Sciences, "Historic-cultural heritage and spiritual values of Russia”.

\section{COMMENTS}

1 The database for the work is the electronic catalogue of world mythology and folklore. Abstracts in Russian and sources of texts see at http://www.ruthenia.ru/folklore/ berezkin. English wordings of the mythological motifs and maps of motifs' areal distribution are at http://starling.rinet.ru/kozmin/tales/index.php?index=berezkin

\section{REFERENCES}

Abramzon, Saul 1946. Ocherk kul'tury kirgizskogo naroda. [An Outline of Kirgiz People Culture.] Frunze: Izdatelstvo Kirg. filiala AN SSSR.

Aikhenwald, Alexandra \& Petrukhin, Vladimir \& Khelimski, Evgeni 1982. K rekonstruktsii mifologicheskih predstavlenii finno-ugorskih narafov. [To the Reconstruction of Mythological Ideas of Finno-Ugrian Peoples.] Balto-slavianskie issledovania 1981. [Baltic-Slavic Studies 1981.] Moscow: Nauka, pp. 162-192.

Aktsorin, Vitali 1991. Mariiski folklor. [Folklore of the Mari.] Yoshkar-Ola: Mariiskoe knizhnoe izdatelstvo.

Alekseenko, Evgeniia A. 1976. Predstavleniia ketov o mire. [The Worldview of Kets.] Vdovin, Innokentii S. (ed.). Priroda i chelovek $v$ religiozny $h$ predstavleniah narodov Sibiri i Severa. [Nature and Man in Religious Ideas of the Peoples of Siberia and the North.] Leningrad: Nauka pp. 67-105.

Alekseev, Nikolai \& Emelianov, Nikolai \& Petrov, V.T. 1995. Predania, legendy i mify sakha (yakutov). [Traditions, Legends and Myths of the Sakha (Yakuts).] Novosibirsk: Nauka.

Allen, Richard Hinckley 1899. Star-Names and Their Meanings. New York \& Leipzig: G. E. Stechert.

Andree, Richard 1878. Ethnographische Parallelen und Vergleiche. Stuttgart: Maier.

Anokhin, Andrei 1997. Legendy i mify sedogo Altaia [Legends and Myths of Old Altai]. Gorno-Altaisk: Ministerstvo kul'tury respubliki Altai.

Ariste, Paul 1974. Vadja muinasjutte ja muistendeid. [Votian Fairy Tales and Legends.] Töid eesti filoloogia alalt, Vol. 4, pp. 3-34.

Ariste, Paul 1977. Vadja muistendid. Tallinn: Valgus.

Ariste, Paul 2005. Komi Fol'klor. [Folklore of the Komi]. Tartu: Estonian Literary Museum. 
Arseniev, Vladimir 1995. Iz nauchnogo nasledia V.K. Arsenieva. [From V. K. Arseniev's Scientific Heritage]. Krayevedcheski biulleten' obschestva izuchenia Sakhalina i Kuril'skih ostrovov, Vol. 4, pp. 151-183.

Ashmarin, Nikolai 1984. Vvedenie v kurs chuvashskoi narodnoi slovesnosti. [Introduction to Chuvash folklore.] Issledovaniia po chuvashskomu folkloru. Cheboksary: Nauchno-iss. inst. iazyka, literatury, istorii i ekonomiki, pp. 3-48.

Azimov, E. \& Tolstoi, Nikita 1995. Astronomia narodnaia. [Folk astronomy.] Slavianskie drevnosti, Vol. 1. Moscow: Mezhdunarodnye otnoshenia, pp. 117-119.

Barag, Lev 1987. Bashkirskoe narodnoe tvorchestvo 2. Predania i legendy. [Bashkir Folk Creative Work. Traditions and Legends.] Ufa: Bashkirskoe knizhnoe izdatelstvo.

Batchelor, John 1927. Ainu Life and Lore: Echoes of a Departing Race. Tokyo: Kyobunkwan.

Beckwith, Martha 1970. Hawaiian Mythology. Honolulu: University of Hawaii Press.

Belova, Ol'ga (ed.) 2004."Narodnaia Bibliia": Vostochnoslavianskie etiologicheskie legendy. ["Folk Bible": Etiological Legends of the Eastern Slavs.] Traditsionnaia dukhovnaia kul'tura slavian: Publikatsiia tekstov. Moscow: Indrik.

Beretti, N.I. 1929. Na krainem Severo-vostoke. [At the Extreme North-East.] Vladivostok: Vladivostokski otdel Gos. Russ. Geogr. obschestva.

Berezkin Yuri 2007. Dwarfs and cranes. Baltic Finnish mythologies in Eurasian and American perspective (70 years after Yrjö Toivonen). Folklore: Electronic Journal of Folklore, Vol. 36, pp. 75-96.

Berezkin, Yuri 2006. The Cosmic Hunt: Variants of a Siberian - North-American Myth. Folklore: Electronic Journal of Folklore, Vol. 31, pp. 79-100.

Bird, Louis 2007. The Spirit Lives in the Mind. Omushkego Stories, Lives, and Dreams. Susan Elaine Gray (ed.) Montreal \& Kingston, London, Ithaca: McGill-Queen's University Press.

Boas, Franz 1895. Indianische Sagen. von de Nord-Pacifischen Kuste Amerikas. Berlin: Asher.

Boas, Franz 1916. Tsimshian mythology. 31th Annual Report of the Bureau of American Ethnology. Washington: Smithsonian Institution, pp. 29-1037.

Boas, Franz 2002. Indian Myths and Legends from the North Pacific Coast of America. Vancouver: Talon Books.

Bogoras, Waldemar 1928. Chuckchee tales. Journal of American Folklore 41, pp. 297 452.

Bogoras, Waldemar 1939. Chukchi 2: Religiia. [Chukchi 2: Religion.] Leningrad: Izdatelstvo Glavsevmorputi.

Boneva, Tania 1994. Naroden svetogled. [Folk Worldview.] Rodopi. Traditsionna duhovna i sotsialno-normativna kultura [The Rhodopes. Traditional Spiritual and Socionormative Culture]. Sofia: Etnografski Institut s Muzei, pp. 7-50.

Brudnyi, Dmitrii \& Eshmambetov, Kasymbek 1968. Kirgizskie skazki. [The Kirgizian folktales.] Moscow: Khudozhestvennaia Literatura.

Burykin, Aleksei 2001. Malye zhanry evenskogo fol'klora. [Small Genres of Even Folklore.] St. Petersburg: Peterburgskoe Vostokovedenie.

Butanaev, Viktor 1975. Predstavleniia o nebesnykh svetilakh v folklore khakasov. [Ideas about Sky Luminaries in Khakas Folklore.] Uchenye zapiski Khakasskogo nauchno-iss. inst. iazyka, literatury i istorii. Seriia filologicheskaia Vol. 20, No. 3, pp. 231-240. 
Caspar, Franz 1975. Die Tuparí. Berlin, New York: de Gruyter.

Chadaeva, Alina 1990. Drevni svet. Skazki, legendy, predania narodov Khabarovskogo kraia. [Ancient World. Folktales, Legends, Traditions of the Peoples of Khabarovsk Territory.] Khabarovsk: Khabarovskoe knizhnoe izdatelstvo.

Charnoluski, Vladimir 1930. Materialy po bytu loparei. [Materials on the Everyday Life of the Lapps.] Leningrad: Izdatelstvo Russkogo Geograficheskogo Obschestva.

Charnoluski, Vladimir 1962. Saamskie skazki. [Saami Folk-Tales.] Moscow: Gosudarstvennoe izdatelstvo khudozhestvennoi literatury.

Chubinskii, Pavel 1872. Trudy etnografo-statisticheskoi ekspeditsii v Zapadno-russki krai. Yugo-zapadny otdel. Materialy i issledovania, sobrannye P. P. Chubinskim. [Proceedings of the Ethnographic-statistical expedition to the West-Russian Territory. Southwestern Department. Materials and Studies supplied by P. P. Chubinskii.] Vol. 1. St. Petersburg: Imp. Russ. Geogr. Obschestvo .

Clay, Charles 1978. Swampy Cree Legends. Bewdley, Ontario: Pine Ridge Publications. Denisov, Piotr 1959. Religioznye verovania chuvash. [Religious Beliefs of the Chuvash.] Cheboksary: Chuvashskoe gos. izdatelstvo.

Deviatkina, Tatiana 1998. Mifologia mordvy. [Mythology of Mordvinians.] Saransk: Krasnyi Oktiabr.

Dixon, Ronald 1916. Oceanic Mythology. Boston: Marshall Jones.

Dolgikh, Boris 1961. Mifologicheskie skazki i istoricheskie predania entsev. [Mythological Folktales and Historical Traditions of the Enets.] Moscow: Izdatelstvo USSR AS.

Dulzon, Andrei 1966. Ketskie skazki. [Ket Folktales.] Tomsk: Izdatelstvo Tomskogo universiteta.

Dulzon, Andrei 1972. Skazki narodov sibirskogo severa. [Folktales of Peoples of the Siberian North.] Tomsk: Izdatelstvo Tomskogo universiteta.

Dybo, Anna 2008. Personal communication.

Egorov, Nikolai 1994. Chuvashskaia mifologiia. [The Chuvash mythology.] Skvortsov, Mikhail (ed.). Kul'tura Chuvashskogo kraia 1. [Culture of Chuvash Region.] Cheboksary: Chuvashskoe knizhnoe izdatelstvo, pp. 109-146.

Egorov, Sergei 2003. Predaniia, legendy i mifologicheskie rasskazy vepsov. [Traditions, legends and mythological tales of the Veps.] Mifologiia i religiia v sisteme kul'tury etnosa. [Mythology and Religion in the Ethnic Cultural System.] St. Petersburg: Rossiiskii Etnograficheskii Muzei, pp. 128-129.

Ellis, Douglas C. (ed.). 1995. Cree Legends and Narratives from the West Coast of James Bay. Winnipeg: The University of Manitoba Press.

Erdödi, József 1968. Finnisch - Ugrische Gestirnnamen. Annales Universitatis Scientiarum Budapestiensis. Philologica, Vol. 8, pp. 105-121.

Ergis, Georgi 1967. Yakutskie skazki. [Yakut Folktales.] Vol. 2. Yakutsk: Yakutskoe knizhnoe izdatelstvo.

Ergis, Georgi 1974. Ocherki po yakutskomu fol'kloru. [Studies in Yakut Folklore.] Moscow: Nauka.

Ernits, Enn \& Ernits, Tiiu 2009. Vadja rahvaastronoomiast 20. sajandil. [Votian Folk Astronomy in the 20th Century.] Paper presented at the annual conference of the Estonian Literary Museum (the Kreutzwald Days), 18th December 2009, Tartu. 
Ernits, Tiiu \& Ernits, Enn 1984. Vadjalaste ja isurite tähelepanekuid taevakehale kohta. [Votians' and Izhorians' Observations on Heavenly Bodies.] Eesti Loodus, Vol. 9, pp. 577-581.

Evseev, Viktor. 1981. Karel'skoe narodno-poeticheskoe tvorchestvo. [People's Poetic Creative Work of the Karelians.] Leningrad: Nauka.

Fielstrup, Feodor 2002. Iz obriadovoi zhizni kirgizov nachala XX veka. [Ritual Life of the Early 20th Century Kirghiz.] Moscow: Nauka.

Galdanova, Galina 1987. Dolamaistskie verovania buriat. [Pre-Lamaistic Beliefs of the Buryats.] Novosibirsk: Nauka.

Gamzatov, G \& Dalgat, Uzdiat 1991. Traditsionnyi fol'klor narodov Dagestana. [Traditional Folklore of the Peoples of Dagestan.] Moscow: Nauka.

Gładyszowa, Mária 1960. Wiedza ludowa o gwiazdach. [Folk Knowledge about Stars.] Wroclaw: Zaklad narodovyim ossolińskich.

Golovnev, Andrei 1995. Govoriaschie kul'tury. Traditsii samodiitsev i ugrov. [Speaking Cultures. Traditions of the Samoyed and the Ugrians.] Ekaterininburg: UrO RAN.

Gura, Aleksandr 1997. Simvolika zhivotnykh v slavianskoi narodnoi traditsii. [Animal Symbols in Slavic Folk Tradition.] Traditsionnaia dukhovnaia kul'tura slavian: Sovremennye issledovaniia. Moscow: Indrik.

Gura, Aleksandr 2006. Lunnye piatna: sposoby konstruirovania mifologicheskogo teksta. [The lunar spots: ways to construct a mythological text.] Slavianski $i$ balkanski fol'klor. [Slavic and Baltic Folklore.] Moscow: Indrik, pp. 460-484.

Gurvich, Ilia 1948. Kosmogonicheskie predstavlenia u naselenia Olenekskogo raiona. [Cosmogonic Ideas among the People of Oleneks District.] Sovetskaia etnografia 3, pp. 128-131.

Gurvich, Ilia 1977. Kul'tura severnyh yakutov-olenevodov. [Culture of Northern Reindeer Yakuts.] Moscow: Nauka.

Hakkarainen, Marina 1999. Interview with Diachkov Yuri Borisovich. Markovo, 02.06.1999. Archive of the European University at Saint-Petersburg.

Hallowell, A. Irving 1934. Some empirical aspects of northern Saulteaux religion. American Anthropologist 36, pp. 389-404.

Harva, Uno 1933. Altain Suvun Uskonto. [Beliefs of Altaic People.] Porvoo, Helsinki: Werner Söderström.

Hirschberg, Walter 1929. Die Plejaden in Afrika und ihre Beziehung zum Bodenbau. Zeitschrift für Ethnologie 61, pp. 321-337.

Holmberg (Harva), Uno 1927. The Mythology of All Races. Vol. IV. Finno-Ugric, Siberian. Boston: Marshall Jones.

Hose, Charles \& McDougall, William 1912. The Pagan Tribes of Borneo. Vol. 2. London: MacMillan.

Ichon, Alain 1969. La Religion des Totonaques de la Sierra. Paris: Centre National de la Recherche Scientifique.

Inoui, Koichi 2005. Personal communication.

Ishida, Eiichiro 1998. Mat' Momotaro. [Momotaro's Mother.] St. Petersburg: Peterburgskoe Vostokovedenie.

Its, Rudolf 1960. Miao. Istoriko-etnograficheskii ocherk. [The Miao. A Sketch of their History and Ethnography.] Moscow, Leningrad: Izdatelstvo USSR AS. 
Iukhma, Mishshi 1980. Zametki o chuvashskoi kosmonimii. [Notes on Chuvash cosmonymy.] Onomastika Vostoka. Moscow: Nauka, pp. 264-269.

Ivanova, Olga 2009. Personal communication.

Janković, Nenad 1951. Astronomija u predanjima, običajima i umotvorinama srba. [Astronomy in the Lore, Customs, and the Folk Wisdom of the Serbians.] Srpski etnografski zbornik, LXIII. Beograd: Naučna knjiga.

Jochelson, Waldemar 1908. The Koryak. Leiden: E.J. Brill; New York: G.E. Stechert.

Jochelson, Waldemar 1961. Kamchadal Texts. 'S-Gravenhage: Mouton.

Jones, William 1919. Ojibwa Texts. New York: Stechert.

Jüvä, Sullõv \& Kauksi, Ülle \& Kõivupuu, Marju \& Reimann, Nele \& Hagu, Paul 1995. ABC kiräoppus ja lugõmik algkooli latsilõ. [ABC Reading and Writing Textbook for Primary School Children.] Võro: Võro Instituut ja Võro Selts.

Kapchits, Georgi L. 1997. Somaliiskie narodnye skazki. [Somalian Folk-tales.] Moscow: Vostochnaia literatura.

Karuts, Richard 1911. Sredi kirgizov i turkmenov Mangyshlaka. [Among the Kirghiz and Turkmenians of Manyshlak.] St. Petersburg: Izdanie A.F. Devriena.

Kerbelyte, Bronislawa 2001. Tipy narodnyh skazanii. [Types of Folk Narratives.] St. Petersburg: Evropeiski Dom.

Khalidova, M. 1984. Folklornye teksty. Primechania k folklornym tekstam. [Folklore Texts. Notes to Folklore Texts.] Mifologia narodov Dagestana. [Mythology of the Peoples of Dagestan.] Makhachkala: Dagestan Branch of URSS AS, pp. 160 187.

Khangalov, Matvei 1958. Sobranie sochinenii. [Complete Works.] Vol. 1. Ulan-Ude: Buriatskoe knizhnoe izdatelstvo.

Khangalov, Matvei 1960. Sobranie sochinenii. [Complete Works.] Vol. 3. Ulan-Ude: Buriatskoe knizhnoe izdatelstvo.

Khasanova, Marina \& Pevnov, Aleksander 2003. Mify i skazki negidal'tsev. [Myths and Tales of the Negidals.] Kyoto: Nakanishi Printing Co.

Khelimski, Evgeni 1982. Samodiiskaia mifologia. [The Samoyed Mythology.] Mify narodov mira. [Myths of the Peoples of the World.] Vol. 2. Moscow: Sovetskaia Entsiklopedia, pp. 398-401.

Khomich, Liudmila 1974. Materialy po narodnym znaniam nentsev. [Materials on the Nenets Folk Knowledge.] Sotsial'naia organizatsia i kul'tura narodov Severa [Social Organization and Culture of the Peoples of the North]. Moscow: Nauka, pp. 231-248.

Koekemoer, Gerhard 2007. Lightning design in an African Content. Pretoria et al.: Tshwane University of Technology.

Konakov, Nikolai et al. 2003. Komi Mythology. Budapest: Akadémiai Kiadó; Helsinki: Finnish Literature Society.

Krappe, Alexander 1938. La Genèse des Mythes. Paris: Payot

Krappe, Alexander 1940. The Lunar Frog. Folk-Lore, Vol. 51, pp. 161-171.

Kreinovich, Erukhim 1973. Nivh-Gu. Moscow: Nauka.

Kulemzin, Vladislav \& Lukina, Nadezhda 1978. Materialy no folkloru khantov. [Materials on Khanty Folklore.] Tomsk: Izdatelstvo Tomskogo universiteta.

Kuperjanov, Andres 2001. Linnutee. [The Milky Way.] Mäetagused, Vol. 16, pp. 107116. 
Kuperjanov, Andres 2003. Eesti taevas. Uskumusi ja tõlgendusi. [Estonian Sky. Beliefs and Interpretations.] Tartu: Eesti Folkloori Instituut.

Lantis, Margaret 1946. The Social Culture of the Nunivak Eskimo. Transactions of the American Philosophical Society, Vol. 35, No. 3, pp. 153-323.

Lashkarbekov, Bogsho 2005. Personal communication.

László, Gáldi 1975. Orosz-magyar kéziszótár. Russko-vengerski slovar'. [HungarianRussian, Russian-Hungarian Dictionary.] Budapest: Akadémiai kiadó.

Laurinkienè, Nijolè 2002. Predstavlenia o mesiatse i interpretatsia vidimyh na nem piaten v baltiiskoi mifologii. Balto-slavianskie issledovania. [Balto-Slavic Studies.] Vol. 15. Moscow: Indrik, pp. 360-385.

Limerov, Pavel 2005. Mu puksiöm - Sotvorenie mira. [Creation of the World.] Syktyvkar: Komi knizhnoe izdatelstvo.

Loorits, Oskar 2000. Liivi Rahva usund. [Beliefs of the Livonian People.] Vol. 4. Tartu: Institute of the Estonian Language.

Lopatin, Ivan 1922. Gol'dy amurskie, ussuriiskie i sungariiskie. [The Amur, Ussuri and Sungari Golds.] Vladivostok: Vladivostokskoe otdelenie priamurskogo otdela Russ. Geogr. Obschestva.

Lukina, Nadezhda 1990. Mify, predania, skazki khantov i mansi.[Myths, Legends, Tales of Khanty and Mansi.] Moscow: Nauka.

Lundmark, Bo 1982. Bæi’vi mánno nástit: sol- och månkult samt astrala och celesta föreställningar bland samerna. Acta Bothniensia occidentalis, Vol. 5. Umea: Västerbotens Museum.

MacDonald, John 1998. The Arctic Sky: Inuit astronomy, star lore, and legend. Toronto: Royal Ontario Museum.

Mahieu, Wauthier de 1975. Cosmologie et structuration de l'espace chez les Komo. Africa, Vol. 45, No. 3, pp. 236-257.

Maksiutova, Nazhiba 1973. Bashkirskaia kosmonimia. Onomastika Povolzhia. Ufa: Bashkirski gos. universitet, pp. 382-384.

Mándoki, László 1963. Asiatische Sternnamen. In: V. Diószegi (ed.) Glaubenswelt und Folklore der sibirischen Völker. Budapest: Akadémiai Kiadó, pp. 519-532.

Marinov, Dimiter. 2003. Narodna viara [Folk Beliefs]. Sofia: Iztok-Zapad.

Matičetov, Milko 1974. Zvesdna imena in izročila o zvezdah med slovenci. Zbornik za zgodovino naravoslovja in tehnike, Vol. 2, pp. 43-90.

McClelland, Catharine 1975. My Old People Say: An Ethnographic Survey of Southern Yukon Territory. Publications in Ethnology No. 6 (1). Ottawa: National Museums of Canada.

McIlwraith, Thomas 1948. The Bella Coola Indians. 2 vols. Toronto: University of Toronto Press.

Meek, Charles 1931. A Sudanese Kingdom: an ethnographical study of the Jukun-speaking peoples of Nigeria. London: Kegan Paul, Trench, Trubner \& Co.

Mickiewicz, Adam 1955. Pan Tadeusz. Selected works in 2 volumes, Vol. 2. Moscow: Gosudarst. izdatelstvo khudozhestvennoi literatury, pp. 277-570.

Miller, Dorcas 1997. Stars of the First People. Boulder: Pruett Pub. Co.

Mladenova, Darina 2006. Zvezdnoto nebo nad nas: etnolingvistichno izsledvane na balkanskite narodni astronimi. [Starry Sky above Us.] Sofia: Akademichno Izdatelstvo "Prof. Marin Drinov". 
Moshkov, Valentin 1900. Mirosozertsanie nashih vostochnyh inorodtsev: votiakov, cheremisov i mordvy. [The World Concept of our Eastern Kin, the Votiaks, Cheremisses and Mordvins.] Zhivaia starina, Vol. 10, No. 1-2, pp. 194-212.

Mudrak, Oleg 2008. Personal communication.

Munkácsi, Bernhard 1908. Die Weltgottheiten der Wogulischen Mythologie. Revue orientale pour les études ouralo-altaïques, Vol. 9, No. 3, pp. 206-277.

Munkácsi, Bernhard 1986. Wogulisches Wörterbuch. Budapest: Akadémiai Kiadó.

Nadrshina, Fanuza 1985. Bashkirskie predania i legendy. [Bashkir Traditions and Legends.] Ufa: Bashkirskoe knizhnoe izdatelstvo.

Napolskikh, Vladimir 1990. Paleoevropeiski substrat v sostave zapadnyh finnougrov. Uralo-Indogermanica, Vol. 2. Moscow: Institut slavianovedenia i balkanistiki USSR AS, pp. 128-134.

Napolskikh, Vladimir 1992. Proto-uralic world picture: a reconstruction. Proto-uralic world picture: a reconstruction. In: M. Hoppál \& J. Pentikäinen (eds.) Northern Religions and Shamanism. Ethnologica Uralica, Vol. 3. Budapest: Akadémiai Kiadó; Helsinki: Finnish Literature Society, pp. 3-20.

Napolskikh, Vladimir 1997. Vvedenie $v$ istoricheskuiu uralistiku. [Introduction into Historic Study of Uralic Languages.] Izhevsk: UrO RAN.

Nekliudov, Sergei et al. 2007. Materialy rossiisko-mongol'skoi fol'klornoi ekspeditsii. [Materials of Russian-Mongolian Folklore Expeditions.] Khubsugul'ski i Bulganski aimaki. Archive of Russian State University of Humanities, Moscow.

Nelson, Edward William 1899. The Eskimo about Bering Strait. Annual Report of the Bureau of American Ethnology to the Secretary of the Smithsonian Institution. Washington: Smithsonian Institution.

Neniang, Lubov' 1997. Khodiachi um naroda. [Current Intelligence of People.] Krasnoyarsk: Fond severnyh literatur "HEGLEN".

Nepokupny, Anatoli 2004. Ot prus. BAYTAN E.346 'SITO’ k PAYCORAN E.6 'PLEIADY' kak sootvetstviu lit. SIEEÝNAS 'to zhe'. Balto-slavianskie issledovania 1981, Vol. 16, pp. 65-82.

Nevski, Nikolai 1996. Luna i bessmertie. [The Moon and Immortality.] Peterburgskoe Vostokovedenie 8, pp. 265-301.

Niebrzegowska, Stanisława 1999. Gwiazdy w ludowym jęzkowym obrazie świata. Językowy obraz świta. Lublin:Wydawnictwo Uniwersytetu Marie Curie-Skłodowskiej, pp. 137-154.

Nikolaeva, Irina \& Zhukova, Liudmila \& Demina, Lubov' 1989. Folklor yukagirov verkhnei Kolymy. Part 1. Yakutsk: Yakutski gos. universitet.

Nikonov, Vladimir 1973. Kosmonimia Povolzhia. Onomastika Povolzhia. Ufa: Bashkirski gos. universitet, pp. 373-381.

Nikonov, Vladimir 1980a. Geografia nazvanii Mlechnogo Puti. Onomastika Vostoka. Moscow: Nauka, pp. 242-261.

Nikonov, Vladimir 1980b. Materialy po kosmonimike Srednei Azii. Onomastika Srednei Azii. Frunze: Ilim, pp. 290-306.

Nimuendaju, Curt 1952. The Tukuna. Berkeley: University of California Press.

Niskanen, Markku 2002. The origin of the Baltic-Finns from the physical anthropological point of view. The Mankind Quartely, Vol. 43, No. 2, pp. 121-153.

Novikova, Klavdija 1987. Evenskie skazki, predania i legendy. Magadan: Magadanskoe knizhnoe izdatelstvo. 
Ostermann, Hother 1942. The Mackenzie Eskimos. After Knud Rasmussen's Posthumous Notes. Copenhagen: Fifth Thule Expedition.

Ostermann, Hother (comp.) 1952. The Alaskan Eskimos as Described in the Posthumous Notes of Dr. Knud Rasmussen. Report of the Fifth Thule Expedition 1921-24, Vol. 10, No. 3.

Ovchinnikov, M. 1897. Iz materialov po etnografii yakutov. [Materials on the Ethnography of the Yakut.] Etnograficheskoe obozrenie, Vol. 3, pp. 148-184.

Pechuël-Loesche, Eduard 1907. Volkskunde von Loango. Stuttgart: Strecker \& Schröder. Peebo, Kadri \& Peegel, Juhan 1989. Igal puul oma juur. Murdetekste Jakob Hurda kogust. [Every Tree Has Roots. Dialectal Texts from Jakob Hurt's Collection.] Tallinn: Eesti Raamat.

Pelikh, Galina 1972. Proiskhozhdenie sel'kupov. [The Origin of the Selkup.] Tomsk: Izdatelstvo Tomskogo universiteta.

Pevnov, Alexander 2008. Personal communication.

Pilsudski, Bronislaw 1912. Ainu folk-lore. Journal of American Folklore, Vol. 25, pp. $72-86$.

Pilsudski, Bronislaw 1991. Folklor ainov. [Ainu Folklore.] Krayevedcheski biulleten' obschestva izuchenia Sakhalina i Kuril'skih ostrovov, Vol. 3, pp. 69-84.

Podmaskin, Vladimir 1991. Duhovnaia kul'tura udegeitsev [Spiritual Culture of the Udihe]. Vladivoskok: Izdatelstvo Dal'nevostochnogo universiteta.

Podmaskin, Vladimir 2006. Narodnye znania tunguso-manchzhurov i nivhov. [Folk Knowledge of Tunguso-Manchurians and Nivkhs.] Vladivoskok: Dal'nauka.

Pogodin, A. 1895. Kosmicheskie legendy baltiiskih narodov. [Cosmic legends of Baltic peoples.] Zhivaia starina, Vol 5, No. 3-4, pp. 428-448.

Popov, Andrei \& Gracheva, Galina \& Taksami, Chuner 1984. Nganasany. [The Nganasans.] Leningrad: Nauka.

Porotov, Georgi \& Kosygin, Vladimir 1969. V strane Kuthi. [In the Land of Kuthi.] Petropavlovsk-Kamchatski: Dal'nevostochnoe knizhnoe izdatelstvo.

Potanin, Grigori 1881. Ocherki severo-zapadnoi Mongolii. [Northwest Mongolia Essays.] Vol. II. St. Petersburg: tip. Kirshbauma.

Potanin, Grigori 1883. Ocherki severo-zapadnoi Mongolii. [Northwest Mongolian Essays.] Vol. IV. St. Petersburg: tip. Kirshbauma.

Potanin, Grigori 1893. Tangutsko-tibetskaia okraina Kitaia i Tsentral'naia Mongolia. [The Tangut-Tibetan Borderlands of China and Central Mongolia.] Vol. 2. St. Petersburg: tip. A. S. Suvorina.

Potanin, Grigori 1919. Mongol'skie skazki i predania [Mongol Folktales and Traditions].Zapiski Semipalatinskogo podotdela Zapadno-sibirskogo otdela Russ. Geogr. obschestva, Vol. 13, pp. 1-97.

Pustylnik, Izold 2002. Astronomicheskoe nasledie drevnih estov. [Astronomic heritage of Ancient Ests.] Astronomia drevnih obschestv. Moscow: Nauka, pp. 283-285.

Rasmussen, Knud 1930. Observations on the Intellectual Culture of the Caribou Eskimos. Report of the fifth Thule expedition 1921-24. Vol. VII. Copenhagen: Gyldendal.

Rassadin, Valentin 1996. Legendy, skazki i pesni sedogo Sayana. Tofalarski fol'klor. [Legends, Folktales and Songs of Old Sayan. The Tofa Folklor.] Irkutsk: Komitet po kul'ture Irkutskoi oblastnoi administratsii. 
Ray, Carl \& Stevens, James 1971. Sacred Legends of the Sandy Lake Cree. Toronto: McClelland \& Steward.

Reed, Alexander 1999. Maori Myths and Legendary Tales. Aukland, Sydney, London, Cape Town: New Holland Publishers.

Rodd, France 1926. People of the Veil. London: MacMillan \& Co.

Rodionov, Vitali 1982. K obrazu lebedia v zhanrah chuvashskogo folklora. [The Swan Image in Chuvash Folklore Genres.] Chuvashski folklor. Cheboksary: Nauchnoiss. inst. iazyka, literatury, istorii i ekonomiki, pp. 150-170.

Rudenko, Sergei 1955. Bashkiry. [The Bashkirs.] Moscow, Leningrad: Izdatelstvo USSR AS.

Rut, Maria 1987. Russkaia narodnaia astronomia. [Russian Folk Astronomy.] Sverdlovsk: Uralski gos. universitet.

Rychkov, Konstantin 1922. Yeniseiskie tungusy. Zemlevedenie, Vol. 1-2, pp. 69-106.

Sanzheev, Garma 1930. Darkhaty. [The Darkhats.] Leningrad: Izdatelstvo USSR AS.

Schefold, Reimar 1988. LIA: Das große Ritual aufden Mentawai-Inseln. Berlin: Dietrich Reimer Verlag.

Schwab, George 1947. Tribes of the Liberian Hinterland. Papers of the Peabody Museum of American Archaeology and Ethnology, Harvard University, Vol. 31. Cambridge: Peabody

Seroshevski, Vaclav 1896. Yakuty. [The Yakuts.] Vol. 1. St. Petersburg: Imp. Russ. Geogr. Obschestvo.

Sharakshinova, Nadezhda 1980. Mify buriat. [Myths of the Buryats.] Irkutsk: Vostochnosibirskoe knizhnoe izdatelstvo.

Sicard, Harald von 1966. Karanga stars. The Southern Rhodesia Native Affairs Department Annual, Vol. 9, No. 3, pp. 142-165.

Sidelnikov, Victor 1962. Kazakhskie skazki. [Kazakh Folktales.] Vol. 2. Alma-Ata: Kazakhskoe gos. izdatelstvo khudozhestvennoi literatury.

Simchenko, Yuri 1966. Traditsionnye verovania nganasan. [Traditional Beliefs of the Nganasans.] Part 1. Moscow: Institut Etnologii i Antropologii RAN.

Sirotkin, Mikhail \& Ivanov, Mikhail (eds.) 1970. Chuvashi. [The Chuvash.] Part 2. Cheboksary: Knizhnoe izdatelstvo.

Skeat, Walter W., \& Blagden, Charles O. 1900. Malay Magic being an introduction to the folklore and popular religion of the Malay Peninsula. London, New York: MacMillan.

Smith, William 1925. The Ao Naga Tribe of Assam. London: MacMillan \& Co.

Sorokina, Irina 2008. Personal communication.

Speck, Frank Gouldsmith 1915. Myths and Folklore of the Timiskaming Algonquin and Timagami Ojibwa. Ottawa: Canada Department of Mines.

Spieth, Jakob 1906. Die Ewe-Stämme. Berlin: Reimer.

Stasevich, Inga 2006. Personal communication.

Steblink-Kamenski, Ivan 2008. Personal communication.

Steinitz, Wolfgang 1966-1993. Dialektologisches und etymologisches Wörterbuch der ostjakischen Sprache. Berlin: Akademie Verlag, pp. 1-15.

Sviatski, Daniil 1961. Ocherki istorii astronomii v Drevnei Rusi. [Studies of the History of Astronomy in Ancient Russia.] Istoriko-astronomicheskie issledovania, Vol. 7. Moscow: Nauka pp. 75-128. 
Swanton, John 1908a. Haida Texts, Masset Dialect. Jesup North Pacific Expedition, Publication 10. Leiden, New York, pp. 273-812.

Swanton, John 1908b. Social conditions, beliefs, and linguistic relationship of the Tlingit Indians. 26th Annual Report of the Bureau of Ethnology. Wash.: Smithsonian Institution, pp. 391-485.

Teit, James 1898. Traditions of the Thompson River Indians of British Columbia. Boston \& NewYork: American Folklore Society.

Teit, James 1909. The Shuswap. Memoires of the American Museum of Natural History, Vol. 4, pp. 443-813.

The Younger Edda. 1970. Mladshaia Edda. Leningrad: Nauka.

Thompson, Terry \& Egesdal, Steven 2008. Salish Myths and Legends. Lincoln \& London: University of Nebraska Press.

Toivonen, Yrjö 1937. Pygmäen und Zugvögel. Finnisch-Ugrische Forschungen, Vol. 24, No.1-3, pp. 87-126.

Tolokonskii, Nikolai 1914. Yakutskie poslovitsy, zagadki, sviatochnye gadania, obriady, poveria, legendy $i$ dr. [Yakut Proverbs, Riddles, Yule-tide Divinations, Rituals, Beliefs, Legends and the Like.] Irkutsk: Tipografia t-va M.P. Okunev \& Co.

Tsenev, Gore 2004. Neboto nad Makedonijata. [Sky above Macedonia.] Skopje: Mladinski Kulturen Tsentar.

Tuchkova, Natalia (ed.) 2004. Mifologia sel'kupov. [Selkup Mythology.] Tomsk: Izdatelstvo Tomskogo universiteta.

Turaev, Vadim (ed.) 2008. Istoria i Kul'tura Nivkhov. [History and Culture of the Nivkh.] Saint-Petersburg: Nauka.

Urazaleev, Ruslan 2007. Natsional'ny fol'klor sibirov Srednego Priirtyshia. [National Folklore of the Sibirs of Middle Irtysh Region.] Internet publication, http:// sybyrlar.narod.ru/folklor, last accessed in Apr 2010.

Vaiškūnas, Jonas 1999. Etnoastronomia litewska. Etnolingwistika, Vol. 11, pp. 165175.

Vaiškūnas, Jonas 2004. Narodnaia astronomia belorussko-litovskogo pogranichia. [Folk Astronomy on the Border Area of Belorus and Lithuania.] Balto-slavianskie issledovania, Vol. 16, pp. 168-179.

Vaiškūnas, Jonas 2006. The Moon in Lithuanian folk tradition. Folklore: Electronic Journal of Folklore, Vol. 32, pp. 157-184.

Valeev, Foat 1976. O religioznyh predstavleniah zapadnosibirskih tatar. [About the Religious Conceptions of West-Siberian Tatars.] Priroda i chelovek $v$ religioznyh predstavleniah narodov Sibiri i Severa. Leningrad: Nauka, pp. 320-331.

Vardugin, Vladimir (ed.) 1996. Mify drevnei Volgi. [Myths of Ancient Volga.] Saratov: Nadezhda.

Vasilevich, Glafira 1936. Materialy po evenkiiskomu (tungusskomu) fol'kloru. [Materials on the Evenk (Tungus) Folklore.] Leningrad: Izdatelstvo Instituta Narodov Severa.

Vasilevich, Glafira 1959. Rannie predstavlenia o mire u evenkov. [Early ideas about the world among the Evenks.] Trudy Instituta Etnografii, Vol. 51, pp. 157-192.

Vasilevich, Glafira 1969. Evenki. [The Evenks.] Leningrad: Nauka.

Vasiliev, M. 1907. Religioznye verovania cheremis. [Religious Beliefs of the Cheremissians.] Ufa: Gubernskaia tip. 
Vathanaprida, Supaporn 1994. Thai Tales: Folktales of Thailand. Englewood: Libraries Unlimited.

Vereschagin, Grigori 1995. Votiaki Sosnovskogo kraia. [The Votiaks of Sosnovo Region.] Izhevsk: UrO RAN.

Vladykin, Vladimir 1994. Religiozno-mifologicheskaia kartina mira udmurtov. [Religious-mythological Worldview of the Udmurts.] Izhevsk: Udmurtia.

Volpati, Carlo 1932. Nomi romanzi degli astri Sirio, Orione, le Pleiadi e le Jadi. Zeitschrift für romanische Philologie, Vol. 52, pp. 152-211.

Volpati, Carlo 1933a. Nomi romanzi delle Orse, Boote, Cigno e altre costellazioni. Zeitschrift für romanische Philologie, Vol. 53, pp. 449-507.

Volpati, Carlo 1933b. Nomi romanzi della Via Lattea. Revue de linguistique romane, Vol. 9, pp. 1-51.

Vorob'ev, Nikolai \& Khisamutdinov, G. 1967. Tatary Srednego Povolzhia i Priuralia. [The Tatars of Middle Volga and Cis-Ural Regions.] Moscow: Nauka.

Voskoboinikov, Mikhail 1960. Evenkiiski fol'klor. [The Evenk Folklore.] Leningrad: Gosudarstvennoe Uchebno-Pedagogicheskoe Izdatelstvo.

Voskoboinikov, Mikhail 1967. Fo'lklor evenkov Pribaikalia. [Folklore of the Baikal Evenks.] Ulan-Ude: Buriatskoe knizhnoe izdatelstvo.

Wichmann, Yrjo 1987. Wotjakischer Wortschatz. Helsinki: Suomalais-ugrilainen Seura.

Williamson, Robert 1933. Religious and Cosmic Beliefs of Central Polynesia, Vol. 1. Cambridge: University Press.

Wolf, Werner 1929. Der Mond in deutschen Volksglauben. Bühl (Baden): Konkordia.

Zhukovskaia, Natalia 1988. Darkhaty. [The Darkhats.] In: Narody Mira. Moscow: Sovetskaia Entsiklopedia, p. 151.

Zolotnitskii, Nikolai 1874. Otryvki iz chuvashsko-russkogo slovaria. [Fragments from Chuvash-Russian Dictionary.] No. 14: chuvashskie nazvania Boga, neba i svetil nebesnyh. [The Chuvash names for God, sky and celestial luminaries.] Kazan: gubernskaia tip.

Zsigmond, Gyözö 2003. Popular cosmogony and beliefs about celestial bodies in the culture of the Hungarians from Romania. Acta Ethnographica Hungarica, Vol. 48, No. 3-4, pp. 421-439. 